\title{
Platelet-Rich Fibrin as a New Approach in Treating Gingival Recession: Systematic Review and Meta-Analysis
}

\author{
Reham AL Jasser ${ }^{1 *}$, Hania AlKudmani ${ }^{2}$ and Sebastiano Andreana ${ }^{2}$ \\ ${ }^{1}$ Department of Periodontics and Community Dentistry, College of Dentistry, King Saud University, Riyadh, Saudi Arabia \\ ${ }^{2}$ Department of Restorative and Implant Dentistry, School of Dental Medicine, State University of New York at Buffalo, USA
}

Received: January 23, 2017; Accepted: January 31, 2017; Published: February 10, 2017

*Corresponding author: Reham AL Jasser, Department of Periodontics and Community Dentistry, College of Dentistry, King Saud University, Riyadh, Saudi Arabia, Tel: 00966534119922; E-mail: r.aljasser@gmail.com

\begin{abstract}
The purpose was to systematically review the effect of platelet rich fibrin (PRF) in the treatment of Miller class I and II recession defects in comparison to conventional surgical procedures. Three electronic databases were searched, and hand search was performed for relevant articles, up to October 2015. All relevant articles were independently screened to specific inclusion criteria. Primary outcomes were Recession Depth (RD), Keratinized Tissue Width (KTW), and Percentage of Root Coverage (\%RC). Secondary outcomes were Clinical Attachment Level (CAL), Probing Depth (PD), Healing Index (HI), and Pain. Ten randomized clinical trials met the inclusion criteria and seven were included in the meta-analysis. No statistically significant difference was found in \% RC between Coronally Advanced Flap (CAF) and CAF + PRF or between CAF + Connective Tissue Graft $(\mathrm{CAF}+\mathrm{CTG})$ and $\mathrm{CAF}+\mathrm{PRF}(p=0.17$ and $p=0.56)$ respectively. $\mathrm{A}$ borderline statistical difference was observed between CAF and CAF $+\operatorname{PRF}(p=0.05)$, and no statistically significance difference between CAF + CTG and CAF + PRF ( $p=0.23)$ in KTW. In regards to pain and healing, a significant reduction in pain during the first 5-7 days and faster healing observed in the PRF intervention when compared to the use of CTG or Enamel Matrix Derivative (EMD). In conclusion, there was no statistical or clinical difference present between PRF and CAF, CAF + CTG, or CAF + EMD for RD, \%RC and KTW when treating Miller class I and II gingival recession. Significant improvement of postoperative pain and healing can be achieved, which may indicate PRF use as an alternative to conventional surgical approaches.
\end{abstract}

Keywords: Soft tissue therapy; Autologous fibrin tissue; Gingival recession; Plastic surgery; Gingival graft

\section{Introduction}

Gingival Recession (GR) is the apical migration of the free gingival margin, in relation to the Cemento-Enamel Junction (CEJ), due to periodontal disease, mechanical factors, underlying bone dehiscence, or post orthodontic movement, among other etiological factors [1]. It has been classified into four categories; depending on the extent of gingival tissue involvement and the level of inter proximal bone [2]. Many Root Coverage (RC) approaches have been proposed including; pedicle flaps; which include coronally advanced flap [3], laterally advanced flap [4], double papilla flap [5]. Others include autogenous grafts such as sub-epithelial connective tissue graft [6], free gingival graft [2], and the use of non-autologous substitutes including; acellular dermal matrix [7], Enamel Matrix Derivatives (EMD), Living Cellular Construct (LCC), and guided tissue regeneration [8]. The choice of surgical modality and material of choice is based on different factors such as degree of recession, location, width of keratinized tissue, gingival tissue biotype, esthetic demands, and patient's preference. CTG has been considered the golden standard for the treatment of GR due to its significant outcomes in complete RC, attachment gain, keratinized tissue gain, and overall long-term treatment stability $[9,10]$. On the other hand, the need for a second surgical site to harvest the CTG is a main disadvantage due to the increased risk of bleeding, pain, and swelling that leads to the need for other RC alternatives [10]. As a result, approaches have been proposed and showed approximately similar results to CTG based treatment and considered an alternative depending on the clinician's and patient's choices; these include: Guided Tissue Regeneration (GTR), Acellular Dermal Matrix Graft (ADMT), and biological materials e.g. Platelet Rich Fibrin (PRF), Platelet Rich Plasma (PRP), Enamel Matrix Derivatives (EMD), among others $[10,11]$.

Platelet Rich Fibrin (PRF) is an autologous cicatricial matrix of fibrin that holds platelets, growth factors and cells within, and is capable of slow releasing them during its natural resorption. PRF membrane is prepared through the centrifugation of autologous blood in the absence of anticoagulants, which result in fibrin clot formation between the Platelet Poor Plasma (PPP) layer at the top and the red blood cells layer at the bottom of the centrifuge tube [12]. That clot is then pressed to release the serum and in turn forms a membrane [13]. A number of growth factors have been identified within the PRF membrane, which are Platelet-Derived Growth Factor (PDGF), Transforming Growth Factor- $\beta 1$ (TGF- $\beta 1$ ), Vascular Endothelial Growth Factor (VEGF), Epidermal Growth Factor (EGF), and Insulin-Like Growth factor-1 [14]. PRF preparation and application is safe, simple, and cost effective. It improves wound healing through the slow 
release of growth factors, angiogenesis, and induction of collagen synthesis, trapping stem cells, aid in fibroblast and osteoblast proliferation, and immune modulation $[15,16]$. It has been widely used in different specialties including; ophthalmology [17], facial rejuvenation [18], regenerative medicine [19], and for hard and soft tissue reconstruction in dentistry including endodontic repair and regeneration [20], treatment of infrabony defects [21], socket preservation [22], maxillary sinus augmentation [23], and guided tissue regeneration $[15,16,24]$.

The aim of this systematic review is to evaluate the effectiveness of PRF as an alternative to conventional surgical therapies on the outcomes of muco-gingival surgery in patients with GR.

\section{Methods}

\section{Study design}

A systematic review focusing on the effect of PRF in the treatment of Miller class I and II GR when compared to conventional surgical therapies treating the same recession types. PRISMA statements checklist for reporting a systematic review was followed [25].

\section{Registration}

A protocol was specified and registered with the International Prospective Register of Systematic Reviews (PROSPERO) on October 2015 (registration number CRD 42015027511), and is available from:

http://www.crd.york.ac.uk/PROSPERO/display_record. asp?ID=CRD42015027511

\section{Eligibility criteria for study inclusion}

Randomized Controlled Clinical Trials (RCT), case-control, cross-sectional and cohort studies were eligible for inclusion. PICO framework was applied as the following:

Population: Adult patients with Miller class-I and II GR, with no periodontal disease.

Intervention: Application of PRF on exposed root.

Controls: Surgical treatment methods used to treat Miller class I and II GR, which include CAF, CTG, FGG, ADMT, and EMD.

Outcomes: primary -Recession Depth (RD), Percentage of Root Coverage (\%RC), and Keratinized Tissue Width (KTW); secondary - Clinical Attachment Level (CAL), Probing Depth (PD), Healing Index (HI), and pain.

\section{Search strategy}

Comprehensive search strategies were established. MEDLINE (via pubmed), EMBASE and CENTRAL databases were searched from the earliest records through October 2015. Unpublished studies, thesis and reference lists were hand searched. Details regarding the search terms are:

(C((gingival recession) OR gingival dehiscence) OR mucogingival defect) OR gingival defect) OR gingival undergrowth AND ((C((Platelet rich fibrin) OR PRF) OR platelet derivatives) OR autologous platelet concentrate) OR platelet growth factors)

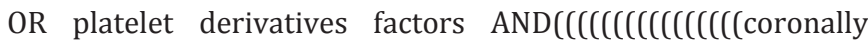
positioned flap) OR coronally advanced flap) OR connective tissue graft) OR laterally positioned flap) OR sliding pedicle flap) OR laterally sliding flap) OR free gingival graft) OR sub epithelial connective tissue graft) OR autologous soft tissue grafts) OR mucogingival graft) OR allogenic soft tissue graft) OR soft tissue graft) OR mucoderm) OR alloderm) OR pedicle flap)) AND (C(C(C(Croot coverage) OR attachment gain) OR keratinized tissue) OR attached tissue) OR area of coverage) OR recession depth) OR gingival biotype) OR gingival thickness) OR gingival recession width).

Relevance Databases were searched without language restrictions using MESH terms, key words and other free terms, and Boolean operators (OR, AND) were used to combine searches.

Relevant articles were screened with no language limitation.

\section{Assessment of validity}

Two independent reviewers (R.J. and H.K.) screened the titles, abstracts and full texts that were identified. Disagreement between the reviewers was resolved through discussion and consensus was reached. Authors were contacted to resolve ambiguity and to retrieve missing data from the trials. Cohen's Kappa score was used to assess inter-reviewer agreement of selection process [26]. The reasons for excluding studies were recorded (Figure 1). Studies meeting the inclusion criteria underwent data extraction and validity assessment.

\section{Data Extraction}

Pre-designed extraction forms were developed to assess the following data: author name(s), publication year and place, source of funding, conflict of interest, study design, sample size, follow-up period, source, selection and description of the study population (including age, gender, race and ethnicity, and presence and characteristics of gingival recession at baseline), definition and measurement method of the intervention, controls, outcomes, results and their variation, and risk of bias.

\section{Data Synthesis}

Data synthesis was preformed through organizing data in an evidence table and a descriptive summary was created to determine study characteristics (Table 1). Descriptive statistical analysis according to the mean values was used to evaluate the outcomes of test and control groups (Table 2).

\section{Quality assessment and risk of bias}

The methodological quality of RCTs included was assessed and recorded in Table 3 according to PRISMA [27].

\section{Results}

The screening process is shown in (Figure 1). Electronic and hand searches yielded 540 articles, of which 12 were selected 


\begin{tabular}{|c|c|c|c|c|c|c|}
\hline $\begin{array}{c}\text { Authors/ } \\
\text { publication year }\end{array}$ & $\begin{array}{l}\text { Study } \\
\text { design } \\
\text { and } \\
\text { Follow- } \\
\text { up }\end{array}$ & $\begin{array}{c}\text { Population size, } \\
\text { Gender, age }\end{array}$ & $\begin{array}{l}\text { Treated teeth, } \\
\text { recession type }\end{array}$ & Intervention & Control & $\begin{array}{l}\text { Outcomes } \\
\text { reported }\end{array}$ \\
\hline $\begin{array}{l}\text { Thamaraiselvan } \\
\text { M. et al., } 2015\end{array}$ & $\begin{array}{l}\text { RCT } \\
6 \mathrm{mo}\end{array}$ & $\begin{array}{c}\mathrm{N}=20 \\
\text { Gender: } 18 \mathrm{M}: 2 \mathrm{~F} \\
\text { Age: } 21-47 \text { years } \\
\text { mean } 34 \text { years }\end{array}$ & $\begin{array}{c}\text { Teeth: } \\
\text { Maxillary and } \\
\text { mandibular teeth } \\
\text { Recession: } \\
\text { Miller class I and II }\end{array}$ & $\mathrm{CAF}+\mathrm{PRF}$ & CAF & $\begin{array}{c}\text { Primary: } \\
\text { RD: mean+ SD (mm) } \\
\text { \%RC: mean+ SD (\%) } \\
\text { KTW: mean+ SD (mm) } \\
\text { Secondary: } \\
\text { PD: mean + SD (mm) } \\
\text { CAL: mean + SD (mm) } \\
\text { Other: RW: mean + SD (mm) } \\
\text { GTH: mean + SD (mm) } \\
\text { PI: mean+ SD (\%) } \\
\text { GI: mean + SD (\%) }\end{array}$ \\
\hline $\begin{array}{l}\text { Keceli HG. et al., } \\
\quad 2015 .\end{array}$ & $\begin{array}{l}\text { RCT } \\
6 \mathrm{mo}\end{array}$ & $\begin{array}{c}\mathbf{N}=40 \\
\text { Gender: } 13 \mathrm{M} \text { : } \\
27 \mathrm{~F} \\
\text { Age: } 22-50 \text { - years } \\
\text { mean } 40.72 \text { years }\end{array}$ & $\begin{array}{l}\text { Teeth: } \\
\text { Maxillary and } \\
\text { mandibular } \\
\text { anteriors and } \\
\text { premolars } \\
\text { Recession: } \\
\text { 34 Miller Class I } \\
6 \text { Miller Class II }\end{array}$ & $\mathrm{CAF}+\mathrm{CTG}+\mathrm{PRF}$ & $\mathrm{CAF}+\mathrm{CTG}$ & $\begin{array}{c}\text { Primary: } \\
\text { RD: mean+ SD (mm) } \\
\text { \%RC: mean+ SD (\%) } \\
\text { KTW: mean+ SD (mm) } \\
\text { Secondary: } \\
\text { PD: mean + SD (mm) } \\
\text { CAL: mean + SD (mm) } \\
\text { Other: RW: mean + SD (mm) } \\
\text { GTH: mean + SD (mm) } \\
\text { PI: mean+ SD (\%) } \\
\text { GI: mean+ SD (\%) }\end{array}$ \\
\hline $\begin{array}{l}\text { Gupta S. et al., } \\
2015\end{array}$ & $\begin{array}{l}\text { RCT } \\
6 \mathrm{mo}\end{array}$ & $\begin{array}{c}\mathbf{N}=26 \\
\text { Gender: } 16 \mathrm{M} \text { : } \\
10 \mathrm{~F} \\
\text { Age: } 20-50 \text { years } \\
\text { mean } 37.17 \text { years }\end{array}$ & $\begin{array}{c}\text { Teeth: } \\
\text { Maxillary anteriors } \\
\text { and premolars } \\
\text { Recession: } \\
\text { Miller class I and II }\end{array}$ & $\mathrm{CAF}+\mathrm{PRF}$ & CAF & $\begin{array}{c}\text { Primary: } \\
\text { RD: mean+ SD (mm) } \\
\text { \%RC: mean+ SD (\%) } \\
\text { KTW: mean+ SD (mm) } \\
\text { Secondary: } \\
\text { PD: mean + SD (mm) } \\
\text { CAL: mean + SD (mm) } \\
\text { Other: PI: mean+ SD (\%) BOP }\end{array}$ \\
\hline $\begin{array}{l}\text { Tunaliota M. et } \\
\text { al., } 2015\end{array}$ & $\begin{array}{l}\text { RCT-SM } \\
12 \text { mo }\end{array}$ & $\begin{array}{c}\quad \mathbf{N}=10 \\
\text { Gender: } 4 \mathrm{M}: 6 \mathrm{~F} \\
\text { Age: } 25-52 \text { years } \\
\text { mean } 34.2 \text { years }\end{array}$ & $\begin{array}{c}\text { Teeth: } \\
\text { Anteriors and } \\
\text { premolars } \\
\text { Recession: } \\
\text { Miller class I and II }\end{array}$ & $\mathrm{CAF}+\mathrm{L}-\mathrm{PRF}$ & $\mathrm{CAF}+\mathrm{CTG}$ & $\begin{array}{c}\text { Primary: } \\
\text { RD: mean+ SD (mm) } \\
\text { \%RC: mean+ SD (\%) } \\
\text { KTW: mean+ SD (mm) } \\
\text { Secondary: } \\
\text { PD: mean + SD (mm) } \\
\text { CAL: mean + SD (mm) } \\
\text { Other: AG: mean + SD (\%) }\end{array}$ \\
\hline $\begin{array}{c}\text { Eren G. et al., } \\
2014\end{array}$ & $\begin{array}{l}\text { RCT-SM } \\
6 \mathrm{mo}\end{array}$ & $\begin{array}{c}\mathrm{N}=22 \\
\text { Gender: } 9 \mathrm{M}: 13 \mathrm{~F} \\
\text { Age: } 18-52 \text { years } \\
\text { mean: } 33 \text { years }\end{array}$ & $\begin{array}{l}\text { Teeth: } \\
\text { Maxillary and } \\
\text { mandibular } \\
\text { anteriors and } \\
\text { premolars } \\
\text { Recession: } \\
\text { Miller class I and II }\end{array}$ & $\mathrm{CAF}+\mathrm{PRF}$ & $\mathrm{CAF}+\mathrm{CTG}$ & $\begin{array}{l}\text { Primary: RD: mean+SD (mm) } \\
\text { (calculated clinically and } \\
\text { digitally) } \\
\text { \%RC: mean+ SD (\%) } \\
\text { KTW: mean+ SD (mm) } \\
\text { Secondary: PD: mean + SD } \\
\text { (mm) } \\
\text { CAL: mean + SD (mm) } \\
\text { Other: RW: mean + SD (mm) } \\
\text { (calculated clinically and } \\
\text { digitally) } \\
\text { GTH: mean + SD (mm) } \\
\text { CRC: number of teeth with } \\
\text { complete root coverage)/(all } \\
\text { treated teeth) X 100: (\%) } \\
\text { RA: mean+ SD (mm }{ }^{2} \text { ) } \\
\text { PI: mean+ SD (\%) } \\
\text { GI: mean+ SD (\%) }\end{array}$ \\
\hline
\end{tabular}




\begin{tabular}{|c|c|c|c|c|c|c|}
\hline $\begin{array}{l}\text { Padma R. et al., } \\
2013\end{array}$ & $\begin{array}{c}\text { RCT-SM } \\
6 \text { mo }\end{array}$ & $\begin{array}{c}\mathbf{N}=15 \\
\text { Gender: Not } \\
\text { mentioned } \\
\text { Age: } 18-35 \text { years } \\
\text { mean: } 26.5 \text { years }\end{array}$ & $\begin{array}{l}\text { Teeth: } \\
\text { Not mentioned } \\
\text { Recession: } \\
\text { Miller class I and II }\end{array}$ & $\mathrm{CAF}+\mathrm{PRF}$ & CAF & $\begin{array}{c}\text { Primary: } \\
\text { RD: mean+ SD (mm) } \\
\text { \%RC: mean+ SD (\%) } \\
\text { KTW: mean+ SD (mm) } \\
\text { Secondary: } \\
\text { CAL: mean + SD (mm) } \\
\text { Other: } \\
\text { PI: mean+ SD (\%) }\end{array}$ \\
\hline $\begin{array}{c}\text { Jankovic S. et al., } \\
2012\end{array}$ & $\begin{array}{c}\text { RCT-SM } \\
6 \text { mo }\end{array}$ & $\begin{array}{c}\quad \mathbf{N}=15 \\
\text { Gender: } 5 \mathrm{M}: 10 \mathrm{~F} \\
\text { Age: } 19-47 \text { years } \\
\text { mean } 33 \text { years }\end{array}$ & $\begin{array}{c}\text { Teeth: } \\
\text { Anteriors and } \\
\text { premolars } \\
\text { Recession: } \\
\text { Miller class I and II } \\
\geq 2 \text { mm in depth }\end{array}$ & $\mathrm{CAF}+\mathrm{PRF}$ & $\mathrm{CAF}+\mathrm{CTG}$ & $\begin{array}{c}\text { Primary: } \\
\text { RD: mean+ SD }(\mathrm{mm}) \\
\text { \%RC: mean+ SD }(\%) \\
\text { KTW: mean+ SD }(\mathrm{mm}) \\
\text { Secondary: } \\
\text { PD: mean + SD }(\mathrm{mm}) \\
\text { CAL: mean + SD (mm) } \\
\text { Other: } \\
\text { HI: score1-5 }\end{array}$ \\
\hline $\begin{array}{c}\text { Jankovic S. et al., } \\
2010\end{array}$ & $\begin{array}{c}\text { RCT-SM } \\
12 \text { mo }\end{array}$ & $\begin{array}{c}\quad \mathbf{N}=20 \\
\text { Gender: } 8 \mathrm{M}: 12 \mathrm{~F} \\
\text { Age: } 21-48 \text { years } \\
\text { mean } 34.5 \text { years }\end{array}$ & $\begin{array}{l}\text { Teeth: } \\
\text { Not mentioned } \\
\text { Recession: } \\
\text { Miller class I and II } \\
\geq 2 \text { mm in depth }\end{array}$ & $\mathrm{CAF}+\mathrm{PRF}$ & $\mathrm{CAF}+\mathrm{EMD}$ & $\begin{array}{c}\text { Primary: } \\
\text { RD: mean+ SD (mm) } \\
\text { \%RC: mean+ SD (\%) } \\
\text { KTW: mean+ SD (mm) } \\
\text { Secondary: } \\
\text { PD: mean + SD (mm) } \\
\text { Other: } \\
\text { HI: score1-5 }\end{array}$ \\
\hline $\begin{array}{l}\text { Aleksic Z. et al., } \\
2010\end{array}$ & $\begin{array}{c}\text { RCT-SM } \\
12 \text { mo }\end{array}$ & $\begin{array}{c}\mathbf{N}=19 \\
\text { Gender: } 8 \mathrm{M}: 11 \mathrm{~F} \\
\text { Age: } 27.5-32.5 \\
\text { years } \\
\text { mean } 30 \text { years }\end{array}$ & $\begin{array}{c}\text { Teeth: } \\
\text { Maxillary canines } \\
\text { and premolars } \\
\text { Recession: } \\
\text { Miller class I and II }\end{array}$ & $\mathrm{CAF}+\mathrm{PRF}$ & $\mathrm{CAF}+\mathrm{CTG}$ & $\begin{array}{c}\text { Primary: } \\
\text { RD: mean+ SD }(\mathrm{mm}) \\
\text { RC: mean+ SD }(\%) \\
\text { KTW: mean+ SD }(\mathrm{mm}) \\
\text { Secondary: } \\
\text { PD: mean + SD }(\mathrm{mm}) \\
\text { CAL: } \text { mean + SD (mm) } \\
\text { Other: } \\
\text { HI: score1-5 }\end{array}$ \\
\hline $\begin{array}{l}\text { Aroca S. et al., } \\
\quad 2009\end{array}$ & $\begin{array}{l}\text { RCT-SM } \\
6 \mathrm{mo}\end{array}$ & $\begin{array}{c}\quad \mathbf{N}=20 \\
\text { Gender: } 5 \mathrm{M}: 15 \mathrm{~F} \\
\text { Age: } 22-47 \text { years } \\
\text { mean } 31.7 \text { years }\end{array}$ & $\begin{array}{l}\text { Teeth: } \\
\text { Maxillary and } \\
\text { mandibular } \\
\text { anteriors, } \\
\text { premolars, molars } \\
\text { Recession: } \\
\text { Miller class I and II }\end{array}$ & $\mathrm{CAF}+\mathrm{PRF}$ & CAF & $\begin{array}{c}\text { Primary: } \\
\text { RD: mean+ SD (mm) } \\
\text { RC: mean+ SD (\%) } \\
\text { KTW: mean+ SD (mm) } \\
\text { Secondary: } \\
\text { PD: mean + SD (mm) } \\
\text { CAL: mean + SD (mm) } \\
\text { Other: } \\
\text { CRC: mean+ SD (\%) } \\
\text { RW: mean + SD (\%) } \\
\text { GTH: mean + SD (mm) }\end{array}$ \\
\hline
\end{tabular}

RCT: Randomized Clinical Trial;SM:Split Mouth Design; Mo:Month; RD:Recession Depth; \%RC:Percentage Root Coverage; KTW:Keratinized Tissue Width; PD:Probing Depth; CAL:Clinical Attachment Level; RW:Recession Width; GTH:Gingival Thickness; PI:Plaque Index; GI:Gingival Index; BOP:Bleeding On Probing; AG:Attachment Gain; CRC:Complete Root Coverage; RA:Recession Area; HI:Healing Index; PN:Pain Index; SD:Standard Deviation

for full-text evaluation after screening their titles and abstracts. Two articles [28,29] were further excluded and reasons are listed in (Figure 1). The $\mathrm{k}$ value for inter-reviewer agreement for potentially relevant articles was 0.95 for full text articles reviewing; indicating an "almost perfect" agreement between the two reviewers [30].

\section{Features of the included studies}

Study design and patient features: Ten RCTs [31-40] were included as shown in Table 1. The age of the participants ranged from 18 to 52 years with a follow-up period ranging from 6 to 12 months. Four included studies compared PRF in conjunction with CAF (PRF + CAF) to CAF alone (CAF) $[31,33,36,40]$ while other four studies compared PRF + CAF to CAF in conjunction with CTG $(\mathrm{CAF}+\mathrm{CTG})[34,35,37,39]$. One study assessed the effect of the addition of PRF to CAF in conjunction to CTG (PRF + CTG + CAF) and compared the results with CAF + CTG [32]. Finally, one trial compared the addition of EMD to PRF utilized with CAF [38].

\section{Sites, recession, and defect characteristics}

Four studies clearly included both maxillary and mandibular 
teeth $[31,32,35,40]$, where as two included maxillary teeth only $[33,39]$. The remaining four studies did not mentioned which arch was treated $[34,36,37,38]$. In regard to the type of teeth treated, six studies included anterior teeth and premolars $(32,33,34,35,37,39]$. While, one study included all teeth [40]. The remaining three studies did not mention the type of teeth treated in a detailed manner $[31,36,38]$. All studies included Miller's class I and II GR; however the exact baseline depth of recession was mentioned in only one study [38].

\section{Protocol for PRF preparation}

All studies followed Choukroun's (2001) protocol in the preparation of PRF [12]. $10 \mathrm{~mL}$ of venous blood was collected from patients and taken to the chair-side centrifuge. A trained auxiliary staff member prepared PRF simultaneously with the surgical procedure. Centrifusion speed ranged between 2500$3000 \mathrm{rpm}$ in a time frame ranged between 10-12 minutes.

\section{Surgical technique}

A full thickness periosteal flap was elevated on the buccal aspect of the tooth being treated in four trials $[31,36,37,39]$, where one of them obtained a trapezoidal full thickness flap by the addition of two vertical incisions starting from its mesial and distal extremities extending beyond the muco-gingival junction [31]. Howeve, the other three did not perform any vertical incisions $[36,37,39]$. In six studies a split-thickness flap with two vertical incisions mesial and distal to the involved tooth was elevated instead [32,33,34,35,38,40]. In Aroca (2009) trial, the surgeon performed a split thickness flap without any vertical incisions [40]. In regards to graft thicknesses, PRF membrane thickness varied among studies between 0.5-2 mm. However, the thickness was only mentioned in two studies [35,39]. In regards to CTG thickness, It ranged between 1-1.5 mm. Final flap position was another factor that varied among studies; In five studies final flap position was $1 \mathrm{~mm}$ coronal to CEJ [31,34,36,37,39] while in the remaining studies it was positioned at the CEJ.

\section{Medications prescribed and post-operative management}

One study gave participants $4 \mathrm{mg}$ Betamethasone and 0.25 $\mathrm{mg}$ of Alprazolam pre-operatively to minimize postoperative swelling and anxiety respectively [40]. Periodontal dressing was utilized in four studies [31,36,37,39]. In terms of postoperative management, six studies covered their patients with Antibiotics $[31,33,34,36,38,40]$, eight prescribed Chlorhexidine mouth rinse $[32,33,34,36,37,38,39,40]$, and eight prescribed Analgesics [31$36,39,40]$.

\section{Outcomes measured}

\section{A. Primary Outcomes: RD, \%RC, and KTW:}

Primary outcomes were reported in all ten studies, two studies revealed that PRF groups had statistically significant more reduction in $\mathrm{RD}[36,38]$, most pronounced difference was shown by Padma (2013) [36] when compared CAF + PRF to CAF alone; authors reported that the mean RD for PRF groups and
CAF groups were $0.00 \pm 0.00 \mathrm{~mm}$ vs. $1.13 \pm 0.72 \mathrm{~mm}$ respectively at 6 months follow up ( $p=0.001)$. Similarly, Jankovic (2010), as comparison was performed between CAF + PRF versus CAF + EMD, the mean RD for CAF + PRF and CAF + EMD groups were $1.05 \pm 0.45 \mathrm{~mm}$ vs. $1.15 \pm 0.65 \mathrm{~mm}$ respectively at one year follow up $(p<0.05)$. In contrast, one study by Aroca (2009) reported less $\mathrm{RD}$ at 6 months for CAF when compared to CAF + PRF measuaring $0.2 \pm 0.4 \mathrm{~mm}$ vs. $0.6 \pm 0.6 \mathrm{~mm}$ respectively ( $p=0.0039$ ) [40]. The remaining seven studies reported no significant difference in RD.

In regards to \%RC, PRF showed a statistically significant improvement in three studies with two of them having a 6 months follow up [32,36] and one with one year follow-up [38]. Keceli (2015) [32] reported mean \%RC for PRF + CAF + CTG versus CAF + CTG of $89.6 \%$ vs. $79.9 \%$ respectively $(p<0.05)$. Padma (2013) [36] reported mean \%RC for PRF + CAF versus CAF alone of $100.00 \pm 0.00 \%$ vs. $68.44 \pm 17.42 \%(p=0.000)$ respectively. Finally, Jankovic (2010) [38] reported significant change favoring CAF + PRF group for a value of $72.10 \pm 9.55 \%$ vs. $70.5 \pm 11.76 \%(p<0.05)$, when compared to CAF + EMD. On the other hand, two studies reported significant difference favoring CAF alone compared to $\mathrm{CAF}+\mathrm{PRF}$ in $\% \mathrm{RC}$ of $91.5 \pm 11.4 \%$ vs. $80.7 \pm 14.7 \%(p=0.0039)$ respectively [40], and favoring CAF + CTG compared to CAF + PRF for $\% \mathrm{RC}$ of $88.56 \pm 7.69 \%$ vs. $79.94 \pm 9.87 \%(p<0.01)$ respectively (Aleksic et al., 2010) [39].

Pamda (2013) [36] showed a statistically significant increase of KTW in sites treated with PRF + CAF when compared to CAF alone measuring $5.38 \pm 1.67 \mathrm{~mm}$ vs. $4.63 \pm 0.81 \mathrm{~mm}$ at the end of the study respectively $(p=0.031)$. In contrast, Aleksic (2010) reported that CAF + CTG showed statistically significant increase in KTW when compared to CAF + PRF with $2.87 \pm 0.43 \mathrm{~mm}$ vs. $2.09 \pm 0.46 \mathrm{~mm}$ at one year $(p=0.013)$ respectively. Similarly, a more recent trial by Jankovic (2012) [37] reported that CAF + CTG significantly increased KTW when compared to CAF + PRF of $2.85 \pm 0.45 \mathrm{~mm}$ vs. $2.20 \pm 0.54 \mathrm{~mm}$ respectively ( $p=0.013$ ).

B. Secondary outcomes: PD, CAL, HI, and pain: PD was reported in nine studies. Only one study showed a statistical significant reduction in PD favoring CAF + PRF compared to CAF + CTG at 6 months follow-up measuring $1.09 \pm 0.29 \mathrm{~mm}$ vs. $1.45 \pm 0.60 \mathrm{~mm}$ respectively $(p=0.017)$ [35]. CAL was documented in nine studies as well, from which only two reported significant difference between test and control groups. Padma (2013) [36] reported statistical significant gain in CAL in CAF + PRF group when compared to CAF alone group for a value of $1.00 \pm 0.00 \mathrm{~mm}$ vs. $2.00 \pm 0.89 \mathrm{~mm}$ respectively $(p=0.002)$. Additionally, Aroca (2009) reported a statistical significant gain favoring CAF alone $(1.37 \pm 0.62 \mathrm{~mm})$ when compared to CAF + PRF $(1.76 \pm 0.97 \mathrm{~mm}$; $p=0.0004$ ).

HI was measured in three studies. Aleksic (2010) [39] scored the healing on a 1-5 index, based on tissue color, response to palpation, granulation tissue, incision margin, and suppuration, where 5 indicated excellent healing and 1 indicating poor healing [41]. It was noted that HI was significantly different in the CAF + PRF group after the first and second weeks of $3.11 \pm 0.25$ and 
$4.25 \pm 0.25$ respectively, than in the control group during the same period $2.25 \pm 0.52$ and $3.05 \pm 0.40$ respectively $(p<0.05)$. Jankovic (2010) used a HI that was based on redness, granulation tissue, bleeding, suppuration and epithelialization for the first and second week post surgery and reported a statistically significant superior healing for the one-week postoperatively in $\mathrm{CAF}+\mathrm{PRF}$ when compared to CAF + EMD $(p<0.05)$. However, this significant difference was absent at the 2 weeks follow up $4.51 \pm 0.21$ vs. $4.29 \pm 0.36(p>0.05)$ respectively. Further, Jankovic (2012) [37] showed enhanced healing values obtained in the CAF + PRF group for the first 2 weeks after surgery in comparison with the CAF + CTG group. Results recorded in the PRF group after 1 and 2 weeks of surgery were $3.11 \pm 0.32$ and $4.20 \pm 0.27$, respectively, while for CAF + CTG were $2.25 \pm 0.54$ and $3.05 \pm 0.38$, respectively $(p<0.05)$. This statistical difference disappeared again at the three weeks follow up $4.51 \pm 0.21$ and $4.29 \pm 0.36$, respectively $(p>0.05)$.

Pain was recorded on a horizontal pain scale, where 0 meant no pain, 1 intermediate pain, and 2 severe pain, before and after the procedure in three studies. Jankovic (2010) [38] assessed post-operative pain for 7 days after the surgery, the authors stated that the pain intensity was significantly different between $\mathrm{CAF}+\mathrm{EMD}$ group and $\mathrm{CAF}+\mathrm{PRF}$ group favoring the later in the first 5 days $0.82 \pm 0.22$ vs. $0.60 \pm 0.33$ ( $p=0.048$ ), and at day 7 this difference was no longer significant between the groups $(p=0.143)$. A more recent study comparing CAF + CTG to CAF + PRF by the same author reported that all patients indicated a greater discomfort in the CTG group, where the pain intensity was statistically different between groups for the first 7 days favoring the CAF + PRF group $0.20 \pm 0.41$ vs. $0.46 \pm 0.51$ ( $p<$ 0.05) [37]. Similarly, Aleksic (2010) [39] indicated that patients treated with $\mathrm{CAF}+\mathrm{PRF}$ reported statistically significant less pain than patients treated with CAF + CTG in the first 7 days postoperatively $2.09 \pm 0.46$ vs. $0.46 \pm 0.51(p<0.05)$ respectively.

\section{Risk of Bias Assessment}

The results of the bias assessment of the included studies are presented in table 3 . None of the studies obtained the highest score in the quality analysis. Allocation concealment was clearly mentioned on only one study [32], as this can bring these studies to uncertain risk of bias [42]. Blinding was not reported in three of the included studies a $[36,39,40]$. None of the studies reported adherence to the CONSORT statement recommendations [25].

\section{Meta Analysis Results}

Meta Analysis was performed separately among studies comparing CAF to PRF + CAF and among studies comparing CAF + CTG to CAF + PRF as followed:

\section{CAF vs. CAF + PRF}

This analysis included four studies [31,33,36,40]. Figure 2 depicts a forest plot with a continuous outcome variable of RD and KTW. A random effect model with confidence interval (CI) of $95 \% .1^{2}=0 \%$ so studies are considered homogenous and it is safe to have confidence that the effects of the intervention being tested are accurate and can be trusted.

\section{RD Change}

When $\mathrm{RD}$ change was assessed from baseline $(0.31[0.08$, $0.54])$ to 6 months follow up (0.23 [-0.10, 0.57]), the black diamond cross the 'line of no effect', the calculated difference between the experimental and control groups is not considered as statistically significant ( $p=0.17) 1^{2}=52 \%$, which is greater than $50 \%$ and studies are very heterogeneous.

\section{KTW Change}

KTW was compared in the same studies between baseline $(0.07[-0.18,0.32])$ and 6 months follow up $(0.21$ [0.00, 0.42]), the change in KTW was considered not statistically significant different $(p=0.05) \cdot 1^{2}=0 \%$, which is less than $25 \%$ and studies are very homogeneous.

The overall studies are considered as homogeneous with $1^{2}=2 \%$, also, the black diamond (with the average effect size of 0.25 ) falls on the right-hand side of the graph that shows studies that received the control condition reported bigger changes than the studies that received the experiment condition.

\section{$\%$ RC at 6 months follows up}

(Figure 3) depicts a forest plot with a continuous outcome variable. We used a random effect model with CI of 95\%. We compare \%RC studies with 6 month, the black diamond (with the average effect size of -3.51) cross the 'line of no effect', the calculated difference between the experimental and control groups is not considered as statistically significant. $(p=0.60) \cdot 1^{2}=$ $56 \%$ and studies are heterogeneous.

\section{CAF + CTG Versus CAF + PRF}

This analysis inlcuded three studies [34,35,37]. Figure 4 depicts a forest plot with a continuous outcome variables of RD and KTW. A random effect model with CI of 95\%. In terms of consistency, $1^{2}=0 \%$, and studies are regarded as highly homogeneous.

RD Change: When change in RD was compared between sites treated with CTG and PRF form baseline $(0.24[0.15,0.32])$ to 6 months follow up $(0.03[-0.08,0.14])$, the black diamond cross the 'line of no effect', the calculated difference between the two groups is not considered as statistically significant $(p=0.56) .1^{2}$ $=36 \%$ and studies are heterogeneous.

KTW Change: KTW was compared in the same studies between baseline $(-0.07[-0.31,0.18])$ and 6 months follow up ($0.29[-0.77,0.19])$, the black diamond cross the 'line of no effect', the calculated difference between the experimental and control groups is not considered as statistically significant $(p=0.23) .1^{2}$ $=36 \%$ and studies are heterogeneous. The average effect size of the overall studies is 0.01 which shows there is no difference between control and experimental studies. 


\begin{tabular}{|c|c|c|c|c|c|}
\hline $\begin{array}{c}\text { Authors/ } \\
\text { publication year }\end{array}$ & $\begin{array}{c}\text { RD }(\mathrm{mm}) \\
\text { Mean } \pm \text { SD } \\
\text { Test } \\
\text { Control }\end{array}$ & $\begin{array}{c}\% \text { RC (\%) } \\
\text { Mean } \pm \text { SD } \\
\text { Test } \\
\text { Control }\end{array}$ & $\begin{array}{c}\text { KTW }(\mathrm{mm}) \\
\text { Mean } \pm \text { SD } \\
\text { Test } \\
\text { Control }\end{array}$ & $\begin{array}{c}\text { PD }(\mathrm{mm}) \\
\text { Mean } \pm \text { SD } \\
\text { Test } \\
\text { Control }\end{array}$ & $\begin{array}{c}\text { CAL }(\mathrm{mm}) \\
\text { Mean } \pm \text { SD } \\
\text { Test } \\
\text { Control }\end{array}$ \\
\hline $\begin{array}{c}\text { Thamaraiselvan M. et } \\
\text { al., } 2015\end{array}$ & $\begin{array}{c}0.70 \pm 0.94 \\
0.90 \pm 0.99 \\
(p>0.05)\end{array}$ & $\begin{array}{c}74.16 \pm 28.98 \\
65.00 \pm 44.47 \\
(p>0.05)\end{array}$ & $\begin{array}{c}2.70 \pm 0.67 \\
2.80 \pm 0.91 \\
(p>0.05)\end{array}$ & $\begin{array}{c}1.00 \pm 0.00 \\
1.00 \pm 0.00 \\
(p>0.05)\end{array}$ & $\begin{array}{c}1.20 \pm 1.39 \\
1.70 \pm 1.25 \\
(p>0.05)\end{array}$ \\
\hline Keceli HG. et al., 2015 & $\begin{array}{c}0.35 \pm 0.52 \\
0.65 \pm 0.59 \\
(p=0.07)\end{array}$ & $\begin{array}{c}89.6 \\
79.9 \\
(p<0.05)^{* *}\end{array}$ & $\begin{array}{l}4.43 \pm 1.48 \\
3.63 \pm 1.37 \\
(p=0.077)\end{array}$ & $\begin{array}{l}1.00 \pm 0.00 \\
1.05 \pm 0.22 \\
(p=0.317)\end{array}$ & $\begin{array}{l}1.35 \pm 0.52 \\
1.70 \pm 0.66 \\
(p=0.064)\end{array}$ \\
\hline Gupta S. et al., 2015 & $\begin{array}{c}0.27 \pm 0.59 \\
0.40 \pm 0.74 \\
(p=0.59)\end{array}$ & $\begin{array}{c}1.00 \pm 19.98 \\
86.60 \pm 23.8 \\
(p=0.59)\end{array}$ & $\begin{array}{c}6.67 \pm 0.49 \\
6.40 \pm 0.51 \\
(p=0.15)\end{array}$ & $\begin{array}{c}1.00 \pm 0.00 \\
1.07 \pm 0.26 \\
(p=0.33)\end{array}$ & $\begin{array}{c}1.27 \pm 0.59 \\
1.47 \pm 0.92 \\
(p=0.48)\end{array}$ \\
\hline $\begin{array}{c}\text { Tunaliota M. et al., } \\
2015\end{array}$ & $\begin{array}{l}1.05 \pm 0.04 \\
0.98 \pm 0.05 \\
(p>0.001)\end{array}$ & $\begin{array}{c}76.63 \\
77.36 \\
(p>0.001)\end{array}$ & $\begin{array}{l}2.86 \pm 0.69 \\
3.03 \pm 0.74 \\
(p>0.001)\end{array}$ & $\begin{array}{l}1.18 \pm 0.33 \\
1.18 \pm 0.35 \\
(p>0.001)\end{array}$ & $\begin{array}{l}2.33 \pm 0.90 \\
2.16 \pm 0.79 \\
(p>0.001)\end{array}$ \\
\hline Eren G. et al., 2014 & $\begin{array}{l}0.18 \pm 0.32 \\
0.16 \pm 0.33 \\
(p=0.787)\end{array}$ & $\begin{array}{c}92.7 \\
94.2 \\
(p=0.674)\end{array}$ & $\begin{array}{l}3.51 \pm 1.28 \\
3.63 \pm 1.43 \\
(p=0.706)\end{array}$ & $\begin{array}{c}1.09 \pm 0.29 \\
1.45 \pm 0.60 \\
(p=0.017)^{* *}\end{array}$ & $\begin{array}{l}1.32 \pm 0.55 \\
1.59 \pm 0.65 \\
(p=0.130)\end{array}$ \\
\hline Padma R. et al., 2013 & $\begin{array}{c}0.00 \pm 0.00 \\
1.13 \pm 0.72 \\
(p=0.001)^{* *}\end{array}$ & $\begin{array}{c}100.00 \pm 0.00 \\
68.44 \pm 17.42 \\
(p=0.000)^{* *}\end{array}$ & $\begin{array}{c}5.38 \pm 1.67 \\
4.63 \pm 0.81 \\
(p=0.031)^{* *}\end{array}$ & Not reported & $\begin{array}{c}1.00+00 \\
2.00 \pm 0.89 \\
(p=0.002)^{* *}\end{array}$ \\
\hline Jankovic S. et al., 2012 & $\begin{array}{l}0.68 \pm 0.45 \\
0.38 \pm 0.48 \\
(p=0.270)\end{array}$ & $\begin{array}{c}88.68 \pm 10.65 \\
91.96+15.46 \\
(p=0.270)\end{array}$ & $\begin{array}{l}2.20 \pm 0.54 \\
2.85 \pm 0.45 \\
(p=0.013)^{*}\end{array}$ & $\begin{array}{l}0.95 \pm 0.41 \\
0.92 \pm 0.48 \\
(p=0.335)\end{array}$ & $\begin{array}{l}1.48 \pm 0.40 \\
1.35 \pm 0.38 \\
(p=0.413)\end{array}$ \\
\hline Jankovic S. et al., 2010 & $\begin{array}{l}1.05 \pm 0.45 \\
1.15 \pm 0.65 \\
(p<0.05)^{* *}\end{array}$ & $\begin{array}{c}72.10 \pm 9.55 \\
70.5 \pm 11.76 \\
(p<0.05)^{* *}\end{array}$ & $\begin{array}{c}1.62 \pm 0.28 \\
1.9 \pm 0.81 \\
(p>0.05)\end{array}$ & $\begin{array}{c}1.23 \pm 0.65 \\
1.60 \pm 0.36 \\
(p>0.05)\end{array}$ & Not reported \\
\hline Aleksic Z. et al., 2010 & $\begin{array}{l}0.70 \pm 0.49 \\
0.39 \pm 0.51 \\
(p=0.270)\end{array}$ & $\begin{array}{c}79.94 \pm 9.87 \\
88.56 \pm 7.69 \\
(p<0.01)^{*}\end{array}$ & $\begin{array}{l}2.09 \pm 0.46 \\
2.87 \pm 0.43 \\
(p=0.013)^{*}\end{array}$ & $\begin{array}{l}0.98 \pm 0.43 \\
0.94 \pm 0.47 \\
(p=0.335)\end{array}$ & $\begin{array}{l}1.44 \pm 0.39 \\
1.36 \pm 0.40 \\
(p=0.413)\end{array}$ \\
\hline Aroca S. et al., $200^{9}$ & $\begin{array}{c}0.6 \pm 0.6 \\
0.2 \pm 0.4 \\
(p=0.0039)^{*}\end{array}$ & $\begin{array}{c}80.7 \pm 14.7 \\
91.5 \pm 11.4 \\
(p=0.0039)^{*}\end{array}$ & $\begin{array}{l}2.54 \pm 0.85 \\
2.37 \pm 0.89 \\
(p=0.1446)\end{array}$ & $\begin{array}{l}1.17 \pm 0.41 \\
1.14 \pm 0.34 \\
(p=0.559)\end{array}$ & $\begin{array}{c}1.76 \pm 0.97 \\
1.37 \pm 0.62 \\
(p=0.0004)^{*}\end{array}$ \\
\hline \multicolumn{6}{|c|}{$\begin{array}{l}\text { RD: Recession Depth; \%RC: Percentage Root Coverage; KTW: Keratinized Tissue Width; PD: Probing Depth; CAL: Clinical Attachment Level; SD: } \\
\text { Standard Deviation } \\
\text { Statistical Significant difference favoring control group* } \\
\text { Statistical Significant difference favoring test group** }\end{array}$} \\
\hline
\end{tabular}

\section{Discussion}

Free Gingival Graft (FGG) and Connective Tissue Graft (CTG) are considered to be the golden standard for the re-establishment of keratinized tissue width and root coverage respectively $[43,10]$. But the accompanying second surgical site, post-operative pain and discomfort had led to the search for other alternatives in the current conservative era where emerging regenerative approaches, as proteins and growth factors, have gained much popularity [44].

Among the alternatives, Enamel Matrix Derivative (EMD) showed strong evidence supporting its use with CAF for root coverage, it had shown long-term ( $>24$ months) stable results comparable to that accomplished by CTG [10].
While acellular dermal matrix (ADMT) resulted in 93\% root coverage compared to $97 \%$ root coverage for CTG in short-term (13 weeks) and 66\% versus $97 \%$ respectively in long-term (49 months) [45]. While GTR resulted in $41 \%$ complete root coverage and $74 \%$ recession depth reduction with attachment and keratinized tissue gain [8].

This review aimed to compare PRF to CTG and its known alternatives (CAF, EMD, ADMT, FGG, and GTR). Findings conclude a comparable final result of RC and gain of KTW in sites treated with PRF in contrast to similar sites treated with the aforementioned conventional surgical approaches. Thus, these findings can enhance the use of PRF as to reduce the need for second surgical site and prevent relevant risks associated. As well as, to prevent high cost associated with growth factors and 


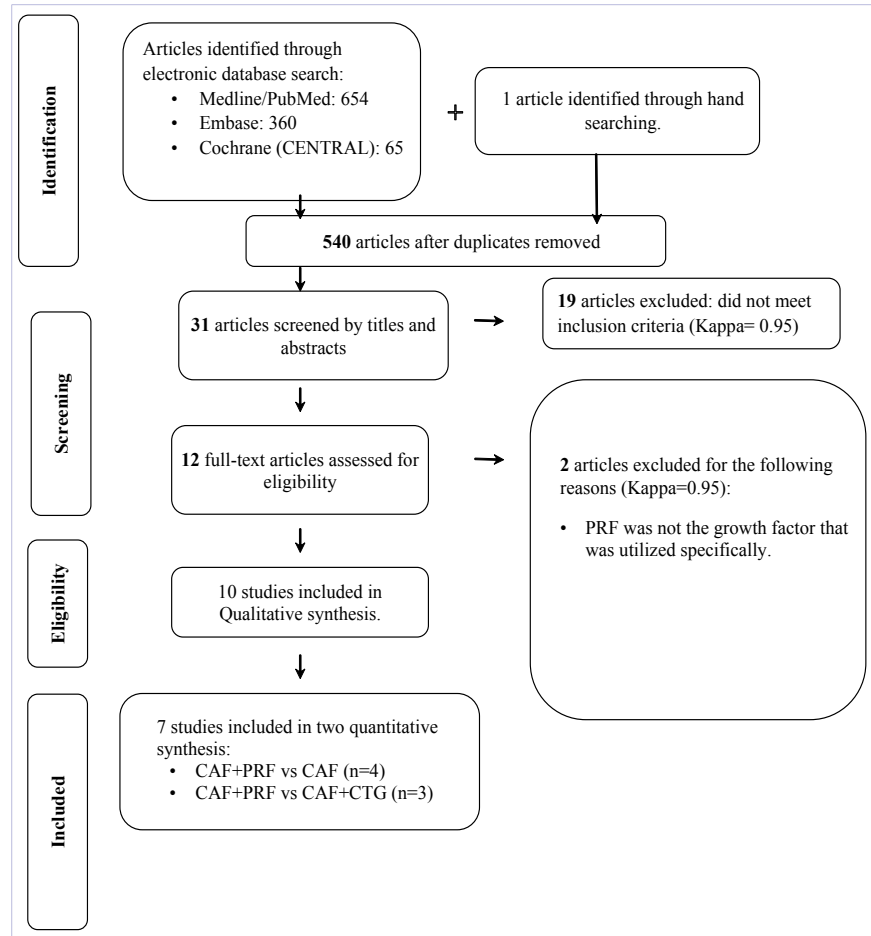

Figure 1: Flow Diagram of Study Selection

accompanied materials used.

Two meta analysis were conducted to gain a more precise comparison of the primary outcomes between CAF and CAF + PRF and between the addition of CTG or PRF. Main results concluded that there was no statistically significant difference in $\mathrm{RC}$ between CAF and CAF + PRF or between CAF + CTG and CAF $+\operatorname{PRF}(p=0.17$ and $p=0.56$ ) respectively, which was consistent with the recently published systematic review on the same topic [46]. In terms of the KTW, a borderline statistical difference was observed between CAF and CAF + PRF $(P=0.05)$, and no statistically significance difference between CAF + CTG and CAF + PRF $(P=0.23)$. The lack of significance between CAF + PRF and $\mathrm{CAF}+\mathrm{CTG}$ was inconsistent with the systematic review published by Moraschini (2016) [46], in which they included seven studies, where they found that the addition of CTG resulted in increased gain in KTW when compared to PRF, the result variation might be explained by the inclusion of two more studies in the present meta analysis comparing the two interventions [32,39]. In these two studies, keceli (2015) found no significant difference between CAF + PRF and CAF + CTG in the gain of KTW ( $p=0.077)$, while Aleksic (2010) found increased gain in KTW favoring CAF + CTG when compared to CAF + PRF ( $p=0.013)$. Also, the present Meta-Analysis found that CAF + PRF did not increase \%RC when compared to CAF alone $(p=0.60)$. In regards to healing and pain assessment, all the three studies that included $\mathrm{HI}$ and pain in their outcomes consistently reported a significant reduction in pain for the first 5-7 days and faster healing in the PRF intervention when compared to the use of CTG or EMD, which was consistent with numerous studies describing faster healing potential of growth factors in regenerative procedures [32,38,39,47-52]. This finding is explained by PRF characteristics, when compared to other forms of blood derived growth factors like PRP, in the slow release of growth factors over a period of 10 days which is the time needed for revascularization and CT formation in a soft tissue regeneration procedure, while PRP was known for an earlier release of growth factors in the healing cascade [53-55]. A meticulous care should be taken in terms of proper handling of PRF, as well as immediate application to recession site after preparation [56,57]. It should be noted that some of the drawbacks for the use of PRF in root coverage procedure is the need to cover the membrane completely to prevent its early resorption, which requires clinical case pre-requisite for a successful coronally advanced flap including; the presence of keratinized tissues, a recession depth not exceeding $4 \mathrm{~mm}$, the presence of a vestibular depth to prevent flap tension, the placement of final flap margin coronal to CEJ, and a tissue biotype thickness of no less than $0.8 \mathrm{~mm}[58,59]$. On the other hand, incomplete coronally advancement of the flap is acceptable for CTG where one-third to one-half can be left exposed to prevent vestibular shortening and increased tension on the flap margins $[6,60]$.

Most of the studies followed the PRF preparation techniques described by Choukroun (2001) [12] but with some variation in time and centrifugation speed which might have affected the RC potential of the PRF membrane, as it has been shown that the increase of centrifugation time from 10 to 12 minutes increased the amount of vascular endothelial growth factor but it did not affect any of the other growth factors or enzymes in the platelet rich fibrin membrane [61]. The lack of histological analysis for the evaluation of regenerative capacity and type of cells populating the previously exposed root surface is another limitation of the current study. More randomized clinical trials with a splitmouth design are needed to overcome the heterogeneity in hostresponse and tissue biotype. Additionally, long-term stability of PRF membrane for RC has to be evaluated in long-term studies.

\section{Conclusions}

This review indicated no statistical or clinical difference in the use of PRF when compared to CAF. This lack of statistical difference makes PRF a comparative alternative to CAF for soft tissue regeneration in the treatment of Miller class I and II gingival recession. The present review showed no difference between $\mathrm{CAF}+\mathrm{PRF}$ vs $\mathrm{CAF}+\mathrm{CTG}$ or $\mathrm{CAF}+\mathrm{EMD}$. Further clinical comparative trials are needed to study the difference between these treatment modalities in order to draw a more valid comparison and conclusions. In addition, it was difficult to withdraw a strong comparison between PRF and EMD since there was only one study included in this review. Finally, the reduced post-operative pain and accelerated healing by the PRF offers an advantage of using it compared to CTG or EMD which also need to be confirmed by future clinical and histological evaluation.

\section{References}

1. Greenwell H, Fiorellini J, Giannobile W, Offenbacher S, Salkin 
L, Townsend C, et al. Oral reconstructive and corrective considerations in periodontal therapy. J Periodontol. 2005;76(9):1588-1600. doi:10.1902/jop.2005.76.9.1588

2. Miller PD Jr. Root coverage with the free gingival graft. Factors associated with incomplete coverage. J Periodontol. 1987;58(10):674681. doi:10.1902/jop.1987.58.10.674

3. Bernimoulin JP, Luscher B, Muhlemann HR. Coronally repositioned periodontal flap. Clinical evaluation after one year. J Clin Periodontol. 1975;2(1):1-13.

4. Grupe HE, Warren RFJ. Repair of Gingival Defects by a Sliding Flap Operation. J Periodontol. 1956;27(2):92-95. doi:10.1902/ jop.1956.27.2.92

5. Cohen DW, Ross SE. The double papillae repositioned flap in periodontal therapy. J Periodontol. 1968;39(2):65-70. doi:10.1902/ jop.1968.39.2.65

6. Langer B, Langer L. Subepithelial connective tissue graft technique for root coverage. J Periodontol. 1985;56(12):715-720. doi:10.1902/ jop.1985.56.12.715
7. Gholami GA, Saberi A, Kadkhodazadeh M, Amid R, Karami D. Comparison of the clinical outcomes of connective tissue and acellular dermal matrix in combination with double papillary flap for root coverage: A 6-month trial. Dent Res J (Isfahan). 2013;10(4):506-513.

8. Al-Hamdan K, Eber R, Sarment D, Kowalski C, Wang HL. Guided tissue regeneration-based root coverage: meta-analysis. J Periodontol. 2003;74(10):1520-1533. doi:10.1902/jop.2003.74.10.1520

9. Chambrone L, Chambrone D, Pustiglioni F, Chambrone L, Lima L. Can subepithelial connective tissue grafts be considered the gold standard procedure in the treatment of Miller class I and II recession-type defects? J Dent. 2008;36(9):659-671. doi:10.1016/j.jdent.2008.05.007

10. Chambrone L, Tatakis DN. Periodontal soft tissue root coverage procedures: a systematic review from the AAP Regeneration Workshop. J Periodontol. 2015;86(2):S8-S51. doi:10.1902/ jop.2015.130674

11. Ramachandra SS, Rana R, Reetike S, Jithendra KD. Options to avoid the second surgical site: a review of literature. Cell Tissue Bank. 2014;15(3):297-305. doi:10.1007/s10561-013-9395-8

12. Choukroun J, Adda F, Schoeffler C, Vervelle A. Une opportunite' en

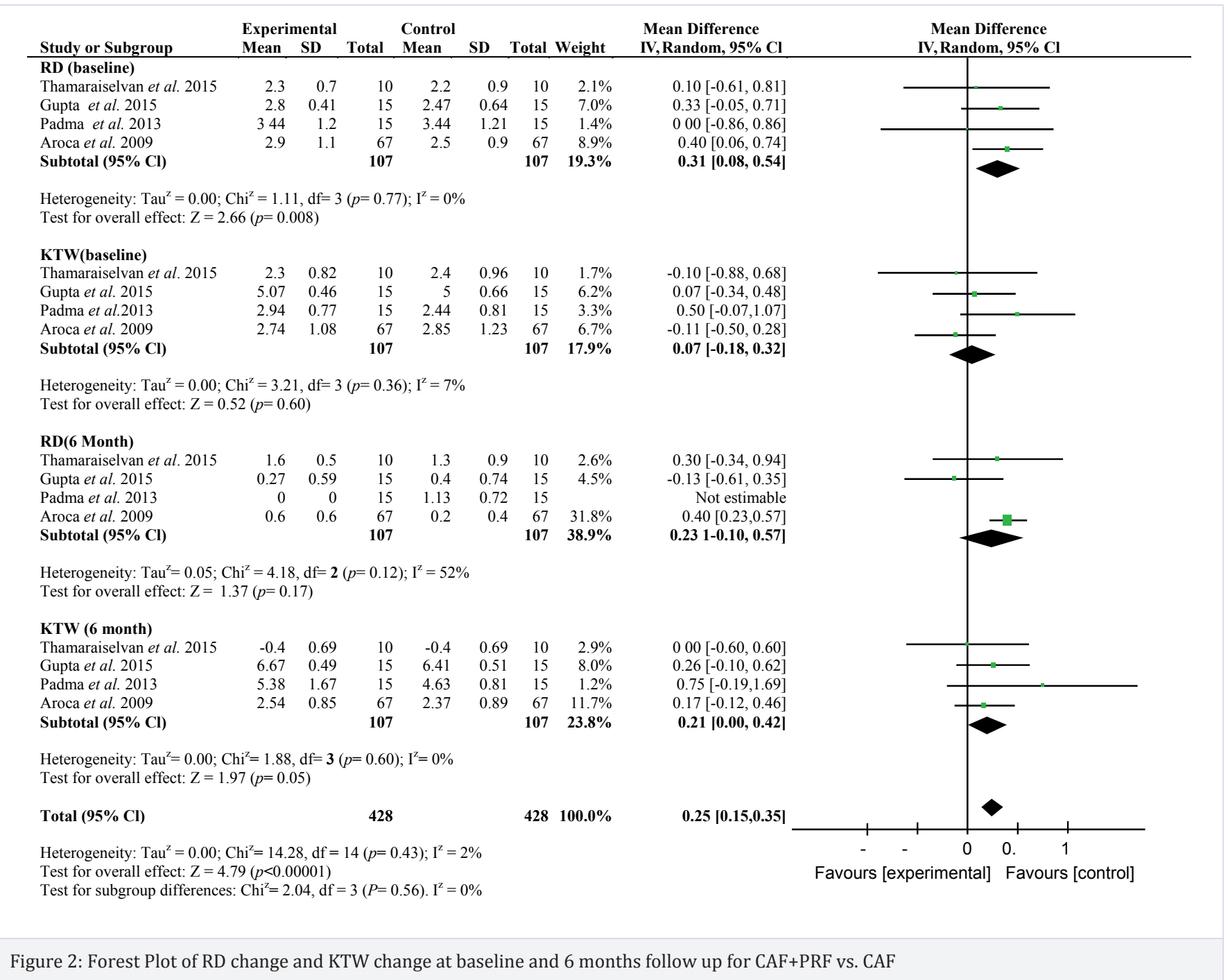

Citation: AL Jasser R, AlKudmani H, Andreana S (2017) Platelet-Rich Fibrin as a New Approach in Treating Gingival Recession: Systematic Review and Meta-Analysis. J Dent Oral Disord Ther 5(2): 1-12. 


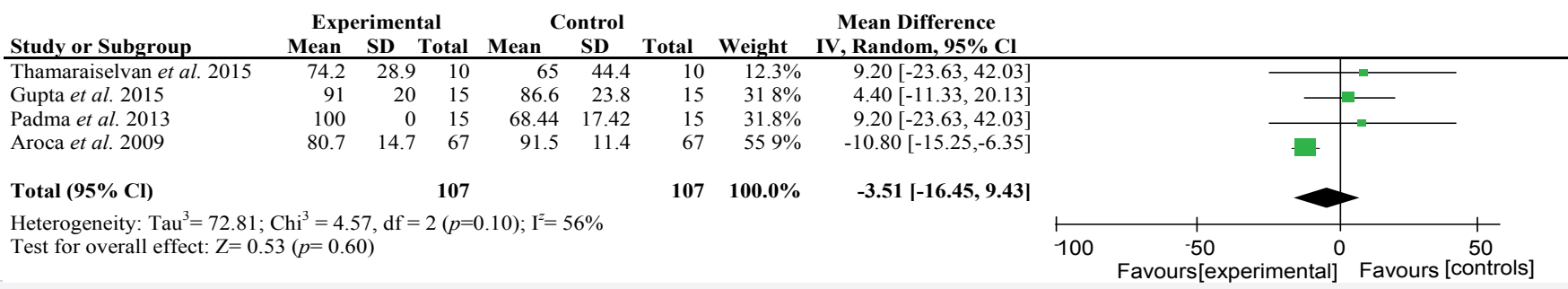

Figure 3: Forest Plot of $\%$ RC change at 6 months follow up for CAF+PRF vs. CAF

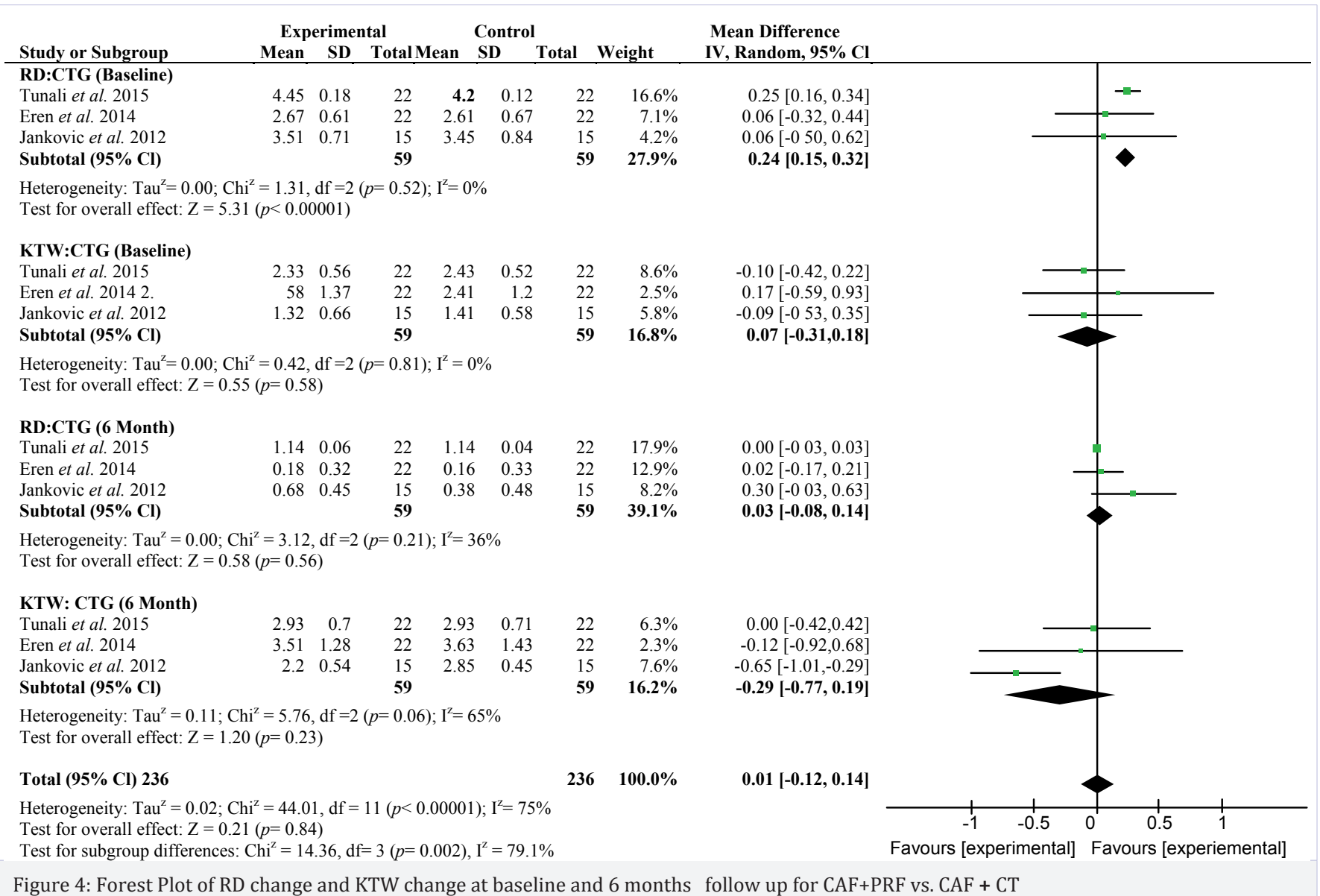

paro-implantologie: le PRF. Implantodontie. 2001;42:55-62.

13. Dohan DM, Choukroun J, Diss A, Dohan SL, Dohan AJ, Mouhyi J, et al. Platelet-rich fibrin (PRF): a second-generation platelet concentrate. Part I: technological concepts and evolution. Oral Surg Oral Med Oral Pathol Oral Radiol Endod. 2006;101(3):e37-44. doi:10.1016/j. tripleo.2005.07.008

14. Su CY, Kuo YP, Tseng YH, Su CH, Burnouf T. In vitro release of growth factors from platelet-rich fibrin (PRF): a proposal to optimize the clinical applications of PRF. Oral Surg Oral Med Oral Pathol Oral Radiol Endod. 2009;108(1):56-61. doi:10.1016/j.tripleo.2009.02.004

15. Agrawal M, Agrawal V. Platelet rich fibrin and its applications in dentistry- a review article. Natl J Med Dent Res. 2014;2(3):51-58.

16. Borie E, Olivi DG, Orsi IA, Katia Garlet, Benjamin Weber, Victor Beltran, et al. Platelet-rich fibrin application in dentistry: a literature review. Int J Clin Exp Med. 2015;8(5):7922-7929.

17. Nugent RB, Lee GA. Ophthalmic use of blood-derived products. Survey of Ophthalmology. 2015;60(5):406-434. doi.org/10.1016/j. survophthal.2015.03.003

18. Sclafani AP, Azzi J. Platelet preparations for use in facial rejuvenation and wound healing: a critical review of current literature. Aesthetic Plast Surg. 2015;39(4):495-505. doi:10.1007/s00266-015-0504-x

19. De Pascale MR, Sommese L, Casamassimi A, Napoli C. Platelet 
derivatives in regenerative medicine: an update. Transfus Med Rev. 2015;29(1):52-61. doi:10.1016/j.tmrv.2014.11.001

20. Hotwani K, Sharma K. Platelet rich fibrin - a novel acumen into regenerative endodontic therapy. Restorative Restor Dent Endod. 2014;39(1):1-6. doi:10.5395/rde.2014.39.1.1

21. Panda S, Doraiswamy J, Malaiappan S, Varghese SS, Del Fabbro M. Additive effect of autologous platelet concentrates in treatment of intrabony defects: a systematic review and meta-analysis. J Investig Clin Dent. 2016;7(1):13-26. doi:10.1111/jicd.12117

22. Del Fabbro M, Corbella S, Taschieri S, Francetti L, Weinstein R. Autologous platelet concentrate for post-extraction socket healing: a systematic review. Eur J Oral Implantol. 2014;7(4):333-344.

23. Ali S, Bakry SA, Abd-Elhakam H. Platelet-rich fibrin in maxillary sinus augmentation: a systematic review. J Oral Implantol. 2015;41(6):746753. doi:10.1563/aaid-joi-D-14-00167

24. Gupta V, Bains V, Singh GP, Mathur A, Bains R. Regenerative potential of platelet rich fibrin In dentistry: literature review. Asian Journal of Oral Health \& Allied Sciences. 2011;1(1):22-28.

25. Moher D, Schulz KF, Altman DG. The CONSORT statement: revised recommendations for improving the quality of reports of parallelgroup randomised trials. Lancet. 2001;357(9263):1191-1194.

26. Cohen J. Weighted kappa: nominal scale agreement with provision for scaled disagreement or partial credit. Psychol Bull. 1968;70(4):213220.

27. Moher D, Liberati A, Tetzlaff J, Altman DG. Preferred reporting items for systematic reviews and meta-analyses: the PRISMA statement J Clin Epidemiol. 2009;339:b2535. doi.org/10.1371/journal. pmed.1000097

28. Lafzi A, Chitsazi MT, Farahani RM, Faramarzi M. Comparative clincal study of coronally advanced flap with and without the use of plasma rich in growth factos in the treatment of gingival recession. Am J Dent 2011;24(3):143-147.

29. Dogan SB, Dede FO, Balli U, Atalay EN, Durmuslar MC. Concentrated growth factor in the treatment of adjacent multiple gingival recession: a split-mouth radomized clinical trial. J Clin Periodontol. 2015;42(9):868-875. doi: 10.1111/jcpe.12444

30. Landis JR, Koch GG. The measurement of observer agreement for categorical data. Biometrics. 1977;33(1):159-174. doi: $10.2307 / 2529310$

31. Thamaraiselvan M, Elavarasu S, Thangakumaran S, Gadagi JS, Arthie T. Comparative clinical evaluation of coronally advanced flap with or without platelet rich fibrin membrane in the treatment of isolated gingival recession. J Indian Soc Periodontol. 2015;19(1):66-71. doi:10.4103/0972-124X.145790

32. Keceli HG, Kamak G, Erdemir EO, Evginer MS, Dolgun A. The adjunctive effect of platelet-rich fibrin to connective tissue graft in the treatment of buccal recession defects: results of a randomized, parallel-group controlled trial. J Periodontol. 2015;86(11):1221-1230. doi: 10.1902/ jop.2015.150015

33. Gupta S, Banthia R, Singh P, Banthia P, Raje S, Aggarwal N. Clinical evaluation and comparison of the efficacy of coronally advanced flap alone and in combination with platelet rich fibrin membrane in the treatment of Miller class I and II gingival recessions. Contemp Clin Dent. 2015;6(2):153-160. doi:10.4103/0976-237X.156034

34. Tunaliota M, Ozdemir H, Arabaciota T, Gurbuzer B, Pikdoken L, Firatli
E. Clinical evaluation of autologous platelet-rich fibrin in the treatment of multiple adjacent gingival recession defects: a 12-month study. Int J Periodontics Restorative Dent. 2015;35(1):105-114. doi:10.11607/ prd.1826

35. Eren G, Atilla G. Platelet-rich fibrin in the treatment of localized gingival recessions: a split-mouth randomized clinical trial. Clin Oral Investig. 2014;18(8):1941-1948. doi:10.1007/s00784-013-1170-5

36. Padma R, Shilpa A, Kumar PA, Nagasri M, Kumar C, Sreedhar A. A split mouth randomized controlled study to evaluate the adjunctive effect of platelet-rich fibrin to coronally advanced flap in Miller's class-I and II recession defects. J Indian Soc Periodontol. 2013;17(5):631-636. doi:10.4103/0972-124X.119281

37. Jankovic S, Aleksic Z, Klokkevold P, Lekovic V, Dimitrijevic B, Kenney $\mathrm{EB}$, et al. Use of platelet-rich fibrin membrane following treatment of gingival recession: a randomized clinical trial. Int J Periodontics Restorative Dent. 2012;32(2):e41-50.

38. Jankovic S, Aleksic Z, Milinkovic I, Dimitrijevic B. The coronally advanced flap in combination with platelet-rich fibrin (PRF) and enamel matrix derivative in the treatment of gingival recession: a comparative study. Eur J Esthet Dent. 2010;5(3):260-273.

39. Aleksic Z, Jankovic S, Dimitrijevic B, Divnic-Resnik T, Milinkovic I, Lekovic V. The use of platelet-rich fibrin membrane in gingival recession treatment. Srpski arhiv za celokupno lekarstvo 2010;138(12):11-18. doi:10.2298/SARH1002011A

40. Aroca S, Keglevich T, Barbieri B, Gera I, Etienne D. Clinical evaluation of a modified coronally advanced flap alone or in combination with a platelet-rich fibrin membrane for the treatment of adjacent multiple gingival recessions: a 6-month study. J Periodontol. 2009;80(2):244252. doi: 10.1902/jop.2009.080253

41.Landry RG, Turnbull RS, Howley T. Effectiveness of benzy damine $\mathrm{HCl}$ in the treatment of periodontal post surgical pa tients. Res Clinic Forums. 1988;10:105-118.]

42. Higgins J, Altman DG. Cochrane handbook for systematic reviews of interventions. Assessing risk of bias in included studies. 2008;187241.

43. Kim DM, Neiva R. Periodontal soft tissue non-root coverage procedures: a systematic review from the AAP Regeneration Workshop. J Periodontol.. 2015;86(2):S8-S51. doi:10.1902/jop.2015.130674

44.Lin Z, Rios HF, Cochran DL. Emerging regenerative approaches for periodontal reconstruction: a systematic review from the AAP Regeneration Workshop. J Periodontol. 2015;86(2 Suppl):S134-152. doi:10.1902/jop.2015.130689

45. Harris RJ. A comparative study of root coverage obtained with an acellular dermal matrix versus a connective tissue graft: results of 107 recession defects in 50 consecutively treated patients. Int J Periodontics Restorative Dent. 2000;20(1):51-59.

46. Moraschini V, Barboza Edos S. Use of platelet-rich fibrin membrane in the treatment of gingival recession: a systematic review and meta-analysis. J Periodontol. 2016;87(3):281-290. doi:10.1902/ jop.2015.150420

47. Nevins M, Camelo M, Nevins ML, Schenk RK, Lynch SE. Periodontal regeneration in humans using recombinant human platelet-derived growth factor-BB (rhPDGF-BB) and allogenic bone. J Periodontol. 2003;74(9):1282-1292. doi:10.1902/jop.2003.74.9.1282

48. Nami N, Feci L, Napoliello L, Giordano A2,3, Lorenzini S4, Galeazzi M, 
et al. Crosstalk between platelets and PBMC: new evidence in wound healing. Platelets. 2016;27(2):143-148. doi:10.3109/09537104.2015 .1048216

49. Anitua E, Sanchez M, Nurden AT, Nurden P, Orive G, Andia I New insights into and novel applications for platelet-rich fibrin therapies. Trends Biotechnol. 2006;24(5):227-234. doi:10.1016/j. tibtech.2006.02.010

50. Choukroun J, Diss A, Simonpieri A, et al. Platelet-rich fibrin (PRF): a second-generation platelet concentrate. part V: histologic evaluations of PRF effects on bone allograft maturation in sinus lift. Oral Surg Oral Med Oral Pathol Oral Radiol Endod. 2006;101(3):299-303. doi:10.1016/j.tripleo.2005.07.012

51. Gassling V, Douglas T, Warnke PH, AcilY, Wiltfang J, Becker ST. Plateletrich fibrin membranes as scaffolds for periosteal tissue engineering. Clin Oral Implants Res. 2010;21(5):543-549. doi:10.1111/j.16000501.2009.01900.x

52. Kumar RV, Shubhashini N. Platelet rich fibrin: A new paradigm in periodontal regeneration. Cell Tissue Bank. 2013;14(3):453-463. doi:10.1007/s10561-012-9349-6

53. Kobayashi E, Fluckiger L, Fujioka-Kobayashi M, Sawada K, Sculean A, Schaller B, et al. Comparative release of growth factors from PRP, PRF, and advanced-PRF. Clin Oral Investig. 2016;20(9):2353-2360. doi:10.1007/s00784-016-1719-1

54. Del Corso M, Vervelle A, Simonpieri A, Jimbo R, Inchingolo F, Sammartino G, et al. Current knowledge and perspectives for the use of platelet-rich plasma (PRP) and platelet-rich fibrin (PRF) in oral and maxillofacial surgery part 1: periodontal and dentoalveolar surgery.| Curr Pharm Biotechnol. 2012;13(7):1207-1230.

55. Dohan Ehrenfest DM, Rasmusson, L, Albrektsson T. Classification of platelet concentrates: from pure platelet-rich plasma (P-PRP) to leucocyte-and platelet-rich fibrin (L-PRF). Trends Biotechnol. 2009;27(3):158-167. doi: 10.1016/j.tibtech.2008.11.009

56. Anilkumar K, Geetha A, Umasudhakar, Ramakrishnan T, Vijayalakshmi R, Pameela E. Platelet-rich-fibrin: a novel root coverage approach. J Indian Soc Periodontol. 2009;13(1):50-54. doi:10.4103/0972$124 X .51897$

57. Saluja H, Dehane V, Mahindra U. Platelet-rich fibrin: a second generation platelet concentrate and a new friend of oral and maxillofacial surgeons. Ann Maxillofac Surg. 2011;1(1):53-57. doi: $10.4103 / 2231-0746.83158$

58. Baldi C, Pini-Prato G, Pagliaro U, Nieri M, Saletta D, Muzzi L, et al. Coronally advanced flap procedure for root coverage. Is flap thickness a relevant predictor to achieve root coverage? a 19case series. J Periodontol. 1999;70(9):1077-1084. DOI: 10.1902/ jop.1999.70.9.1077

59. Hwang D, Wang HL. Flap thickness as a predictor of root coverage: a systematic review. J Periodontol. 2006;77(10):1625-1634. doi:10.1902/jop.2006.060107

60. Chambrone L, Sukekava F, Araujo MG, Pustiglioni FE, Chambrone LA, Lima LA. "Root-coverage procedures for the treatment of localized recession-type defects: a Cochrane systematic review. J Periodontol.2010;81(4):452-478. doi:10.1902/jop.2010.090540

61. Eren G, Gurkan A, Atmaca H, Donmez A, Atilla G. Effect of centrifugation time on growth factor and MMP release of an experimental plateletrich fibrin-type product. Platelets. 2016;27(5):427-432. doi: $10.3109 / 09537104.2015 .1131253$ 